\title{
THE EMBLEMATIC HANDKERCHIEF IN OTHELLO, AND ITS UNTOLD BACKSTORY
}

\author{
EL PAÑUELO EMBLEMÁTICO DE OTHELLO, Y SU TRASFONDO \\ NO CONTADO
}

\author{
Tamara A. Goeglein \\ Department of English, Franklin \& Marshall College
}

\begin{abstract}
Early modern emblems intentionally performed aspects of one's character that elicited curiosity while conveying secret messages, often amorous and at times shared by lovers. Emblems could be engraved in medallions, affixed to jewelry, printed in books, and sewn into textiles, such the strawberry motif embroidered in the handkerchief Othello gives Desdemona in Shakespeare's play, The Tragedy of Othello, the Moor of Venice. Most critics interpret the emblematic handkerchief for what it comes to mean in the play, whereas I explore how it could have meant when Othello initially gives it to Desdemona. Why would a chivalric warrior give his lady such a handkerchief? And what could this gesture tell us about Othello and Desdemona before the play opens? In my untold backstory, Othello's giving Desdemona his emblem is his entrusting her with his worst fear -a military ambush. Their love transforms this fear, however, into an unguarded strength that tragically leaves him vulnerable to an ambush of his soul.
\end{abstract}

KEYWORDS: emblematics; theatre; Shakespeare; Othello.

RESUMEN: Los primeros emblemas modernos promovían intencionalmente aspectos que suscitaban curiosidad mientras transmitían mensajes secretos, a menudo amorosos y a veces compartidos por los amantes. Los emblemas podían ser grabados en medallones, colocados en joyas, impresos en libros y cosidos en textiles, como el motivo de la fresa bordada en el pañuelo que Otelo entrega a Desdemona en la obra de Shakespeare, The Tragedy of Othello, the Moor of Venice. La mayoría de los críticos interpretan el emblemático pañuelo como un presagio de lo que va a ocurrir en la obra, mientras en este artículo se explora cual podría ser el significado e intención de Otelo al hacerle entrega del mismo a Desdemona. ¿Por qué un guerrero caballeresco regalaría a su señora un pañuelo? ¿Y qué podría decirnos este gesto sobre Otelo y Desdemona antes de que se incie la obra? Según la interpretación que se defiende en este trabajo, el trasfondo de este asunto es que Otelo entregó a Desdemona su emblema confiándole su peor temor: una emboscada militar. Su amor transforma este miedo, sin embargo, en una fuerza desprotegida que trágicamente lo deja vulnerable a una emboscada de su alma.

PALABRAS CLAVES: emblemática; teatro; Shakespeare; Otelo. 

blem.

Stage p Daly rop. Luxury item. Talisman. Love token. Commodity. Objet a. Fetish. Em-

The embroidered handkerchief Othello gives Desdemona has been called all of these names, but none more insistently than emblem. Critics have claimed the handkerchief is an emblem of "Desdemona's reputation" (Hodgson, 1977: 314) and a "phallic emblem» of Desdemona's castration (Green, 1977: 110). We know that the handkerchief was "spotted with strawberries," as Iago says (3.4.431), and, with this detail, Lynda Boose argues it is an emblem of "virginal blood," of "the marital blood pledge," and of the "consummated value» of Desdemona and Othello's marriage (Boose, 1994: 56, 59, 61). ${ }^{1}$ Lawrence J. Ross suggests that the strawberry design was as likely drawn from religious iconography of the Virgin Mary as it was drawn from early modern emblem books (Ross, 1960: 229; 234). Emblem books, I would add, provided patterns for making personalized insignias in jewelry, armor, and textiles. ${ }^{2}$ Renaissance humanist Leon Battista Alberti took the hieroglyphic "winged eye" as his emblem, which appears in his medallion portraits and on his hatpin. ${ }^{3}$ In Baldesar Castiglione's sixteenth-century Book of the Courtier, we learn that the Duchess of Urbino wore a headband with a mysterious "S" affixed to it (1959: 21). Early modern emblems intentionally performed aspects of one's character that elicited curiosity while conveying secret messages, often amorous and at times shared by lovers. In this sense, I would call Othello's emblem the strawberry motif fabricated in the handkerchief, and I would call the strawberry motif emblematic of his marriage to Desdemona.

In 1522, Andrea Alciato, the Italian jurist credited with inventing emblems, wrote in a letter to his publisher Francesco Calvo that an emblem is "an epigram which describes something, so that it signifies something else." Alciato writes:

I give in each separate epigram a description of something, such that it signifies something pleasant taken from history or from nature, after which painters, goldsmiths and founders can fashion objects which we call badges and which we fasten on our hats, or else bear as trade-marks. (Miedema, 1968: 238)

Alciato's notion of the emblem as epigrammatic poetry shifted over the next decade when, in the Emblematum liber (1531), the Augsburg printer Heinrich Steyner supplemented the epigrams with woodcut images. By 1534, in Chrestien Wechel's Paris edition of the Emblematum libellus, Alciato's emblems take on the tripartite format of motto, picture, and verse that many of us today take as normative. ${ }^{4}$ The development of the emblem -and its terminologies and taxonomies- is more complicated, however, with early modern emblem theorists writing histories of it and offering definitions of it and suggesting uses of it that are neither entirely consistent nor uniform. Alciato's emblems are the pater et princeps of the genre, which from the outset provided patterns for the decorative arts painted, carved, sewn and printed throughout early modern Europe.

1. All references to Shakespeare's plays are from The Norton Shakespeare (2016), with specific citations noted parenthetically.

2. P. Daly has written extensively on emblematics, and, in his most recent book The Emblem in Early Modern Europe (2014), he addresses the wide-ranging nomenclature used by both their makers and interpreters, such as emblem, device, imprese, epigram, and conceit (7, fn.22). As the title of his book suggests, emblem is probably the most inclusive term and thus I use it. For more about emblems in material culture, see Daly's The English Emblem and the Continental Tradition (1988).

3. See L. Schneider (1990) for an explication of Alberti's emblem.

4. See, Alciato at Glasgow http://www.emblems.arts.gla.ac.uk/alciato (August 1, 2016). 
The Victorian scholar Henry Green was probably the first to call attention to Shakespeare's use of emblem books for his poetic and theatrical works. Green's Shakespeare and the Emblem Writers (1870) is as much an extensive catalog of English and Continental emblem books as it is an indefatigable review of Shakespeare's allusions to emblems. It is an admirable source-study, the work of a connoisseur whose critical apparatus strikes me as not unlike a Renaissance commonplace book. Green notes, for example, that Lady Macbeth's advice to her husband, "Look like t'innocent flower, / But be the serpent under't» (Macbeth, 1.5.63-64), likely refers to Claude Paradin's emblem Latet anguis in herba ("a snake lurks in the grass»), which is found in his Devises Herö̈ques (1562; Green, 1870: 340-41) [fig. 1]. Green notes that Geffrey Whitney's Choice of Emblemes (1586) also includes Latet anguis in herba [fig. 2] and that its proverbial wisdom can be found in Shakespeare's 2 Henry 6 ( "Or as the snake, rolled in a flowering bank," 3.1.228) and Romeo and Juliet ("O serpent heart, hid with a flow'ring face," 3.2.73). Green's volume, while limited by his access to emblem books now easily available, is nonetheless a rich resource for us interested in Shakespeare and emblems. ${ }^{5}$

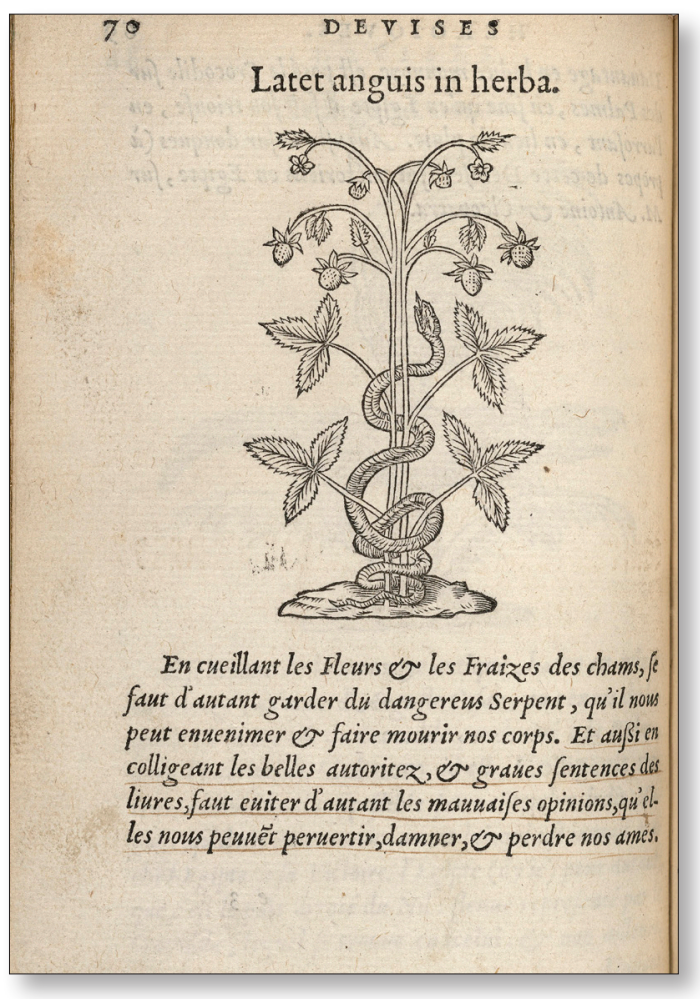

Fig. 1 . Latet anguis in herba. Claude Paradin, Devises Heroiques (1557), p. 70. Used by permission of the Folger Shakespeare Library under a Creative Commons Attribution-ShareAlike 4.0 International License.

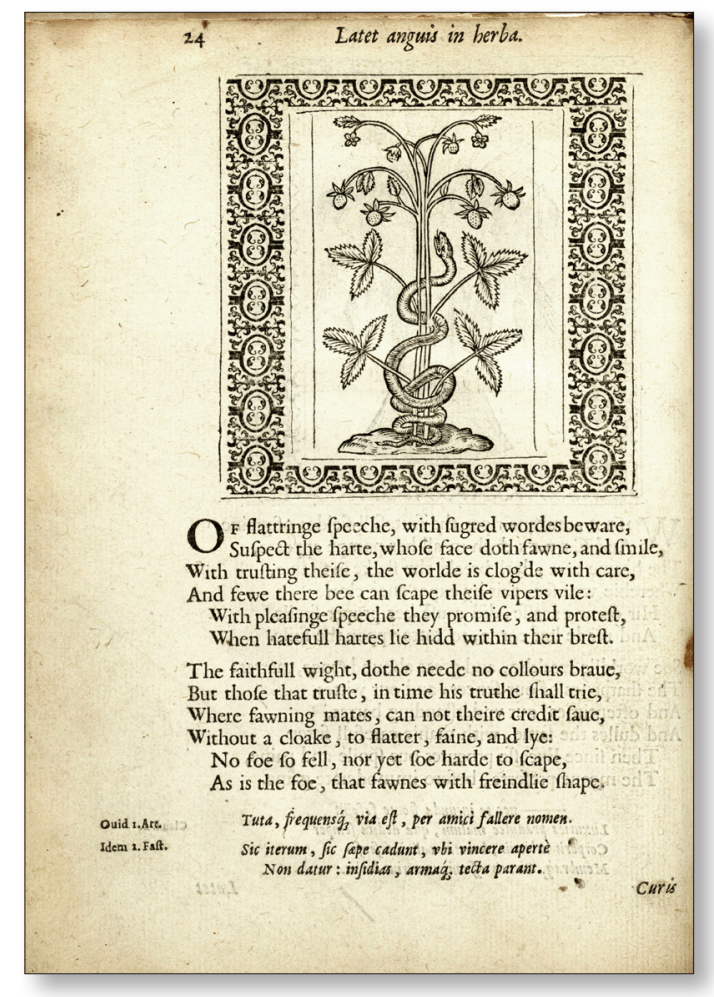

Fig. 2 . Latet anguis in herba. Geffrey Whitney, Choice of Emblemes (1586), p. 24. The English Emblem Book Project. Digital Collections, University Libraries, Pennsylvania State University. https://collection l.libraries. psu.edu/cdm/compoundobject/collection/emblem/ $\mathrm{id} / 551 / \mathrm{rec} / 8$ (accessed August 21, 2016).

5. P. Daly (1979) and R. Freeman (1966) generally discuss emblems in drama. J. Hunt discusses the critical limitations of approaches like theirs, and I share his view (1989).

IMAGO, NÚM. 8, 2016, 61-75 
When most critics today call the handkerchief in Othello an emblem or emblematic, they do not mean what Green meant or what Alciato and other early modern emblematists (however various) meant. When Lynda Boose calls the handkerchief an emblem of Othello and Desdemona's sexual intercourse ("the emblem of the symbolical act of generation»), she does not mean that the emblematic embroidery was devised to signify this (1994: 56): she devises this meaning and attributes it to the handkerchief. When John Hodgson calls it «an emblem of Desdemona's reputation" (1977: 314) and when Andre Green calls it «a phallic emblem" of her castration (1977: 110), they do not mean the strawberry-embroidered handkerchief was devised to signify this: they attribute these meanings by an interpretive act of metonymic association. Likewise, when Stephen Greenblatt says that Iago's impromptu, invisible power-plays exhibit "a mastery whose emblem is the 'duteous and knee-crooking knave' who 'dotes on his own obsequious bondage,'” (Othello, 1.1.43-44), Greenblatt does not mean that Iago actually took on such an emblematic badge: Greenblatt styles Iago's self-fashioning psychodrama as an emblem, although Greenblatt's astute use of the term points to the secretive, enigmatic qualities of the emblem (1980: 233). Emblems engaged the serio-ludere ( to play seriously») culture in which Shakespeare lived and, in this way, emblems were deliberately performative. When Shakespeare's characters adopt an emblem, as I believe Othello did, we can imagine the emblem and the drama it evokes as a play-within-a-play with its potential for suggesting interpersonal dynamics.

Ross traces the strawberry motif through emblem books and sees it at play in Henry 5 ("The strawberry grows underneath the nettle,» 1.1.60) and in Richard 3 ("When I was last in Holborn, / I saw good strawberries in your garden there," 3.4.36-37). In both these instances, the strawberry motif is associated with the titular kings, and Ross links the motif to the emblem Latet anguis in herba because the English version of Paradin's emblems, The Heroicall Devises of M. Claudius Paradin (1591), translated its French verse commentary as: «In gathering of flowers, and strawberries that grow low vpon the ground, we must be verie carefull for the adder and snake that lieth lurking in the grasse" [fig. 3]. The strawberry was said to be immune to evil infection from its neighboring flora and fauna. Ross, when he considers Shakespeare's "references to the strawberry from an emblematic point of view," says "we might guess that it could have been used as an emblem of either the good or uncorrupted man, or of the seemingly good man, the hypocrite» (1960: 226-29). Ross's guessing is not unlike the royal advisers of King Richard 3 and King Henry 5, whose references to strawberries create meta-dramatic contexts for surmising character traits in their opaque sovereigns. Ross also sees a ubiquitous presence of the strawberry in depictions of the Virgin Mary, so that, when he turns to Othello, he combines the Virgin Mary iconography with the strawberry emblem to argue that the handkerchief represents "Othello's distorted version of Desdemona as perilously deceitful beauty, as the adulterous and hypocritical fair woman" (1960: 239). This may be a way for us to understand what the emblematic handkerchief comes to mean in the play. My question, however, is what did the emblematic handkerchief mean before he gave it to her? Or, when he gave it to her?

Othello tells those gathered at the end of the play that the handkerchief was a «recognizance and pledge of love/ Which I first gave her.» It was, he continues, "an antique token / My father gave my mother» (my emphasis, 5.2.209-12). Earlier in the play, when Emilia finds it in Desdemona's room, she says to herself, "This was her first remembrance from the Moor" (my emphasis, 3.3.289). And, when she gives it to her husband, they have this exchange: 

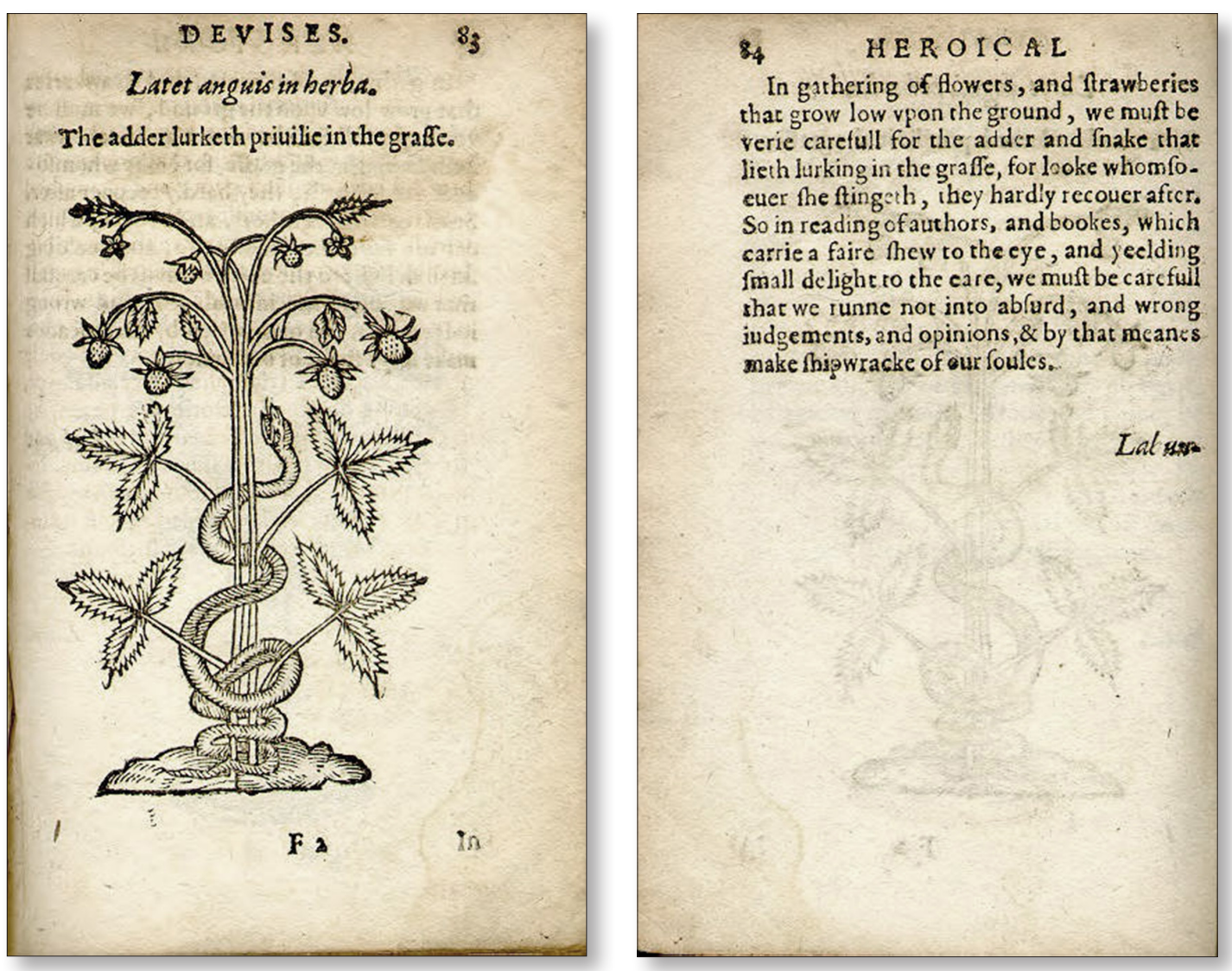

Figs. 3a \& 3b . Latet anguis in herba. The Heroicall Devises of M. Claudius Paradin, Whereunto are Added the Lord Gabriel Symeons and Others. Translated out of our Latin into English by P.S. (1591), p. 83-84. The English Emblem Book Project. Digital Collections, University Libraries, Pennsylvania State University. https://collection l.libraries. psu.edu/cdm/ref/collection/emblem/id/2277 (accessed August 21, 2016).

Emilia: What will you give me now For that same handkerchief?

Iago: What handkerchief?

Emilia: What handkerchief?

Why, that the Moor first gave to Desdemona:

That which so often you did bid me steal.

Iago: Hast thou stolen it from her?

Emilia: No, but she let it drop by negligence,

And to th'advantage I, being here, took't up

Look, here 'tis. (my emphasis, 3.3.303-11)

There is little doubt that Othello gives Desdemona the handkerchief at the beginning of their relationship. Perhaps, as a pledge of engaged commitment? Or, as a wedding gift, as a marital pledge? In any event, to Ross's point, it is implausible that Othello would at first see Desdemona as an adulterous hypocrite, so that the embroidered handkerchief could not have initially meant this to Othello, even while it could come to mean this for us, and for him. 
What the handkerchief comes to mean is complicated by Othello's telling Desdemona, after Emilia stole it and gave it to Iago, that it is charmed, that an Egyptian sibyl wove it for his mother with such magic that it "would subdue my father / Entirely to her love" (3.4.5657). Should his mother lose it or give it away, Othello continues, «my father's eye / Should hold her loathed, and his spirits should hunt / After new fancies" (3.4.58-60). Desdemona seems stunned by this revelation, and, once Othello leaves, she and Emilia ponder Othello's mood and his tale:

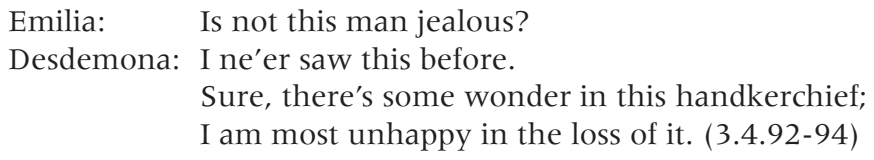

Most obviously, Desdemona is shocked by Othello's mood and tale, both of which are new to her. Less obviously, she does not admit to losing the handkerchief (and we know she neither lost it nor gave it away), neither does she admit it is charmed, magic, or prophetic-she says "there's some wonder» in it, as in, she is astonished or puzzled by its new effect on Othello. I am astonished that Desdemona never says anymore about this tale, even after Othello strikes her and calls her his "mistress" in public (4.1.227-37). Even after he calls her "that cunning whore of Venice» (4.2.88). Only on her deathbed does the couple even discuss the handkerchief again, he to accuse her of giving it to Cassio and she to deny it. She says: «He found it, then. / I never gave it him» (5.2.67-68). Only here can we detect an indirect reference to the tale and a dying refusal to admit she lost the handkerchief or gave it away. We of course know this to be true and can only surmise that Othello tells the magical tale as a desperate threat.

What the handkerchief comes to mean for Othello is not what it initially meant to him and certainly never to Desdemona. To wonder what the handkerchief first meant to Othello and why he gave it to Desdemona engages the critical debate about character-based approaches to Shakespearean drama. That is, to what extent do we think about dramatis personae as real persons? Have they private, inner lives about which we make inferences? How universal are their lives and subjectivities? Theatre practitioners usually ask these questions, and actors delivering a line one way or another can radically shift our interpretation of character. Yu Jin Ko explores the single half-line Othello speaks to Brabantio, "Her father loved me» (1.3.127), which an actor recently uttered as if to say to him, "Don't you remember?» (2012: 1). With this, the actor opened a window into Othello's inner life and his secret marriage to Desdemona. Why did they marry in secret? How did the couple -in tandem or alone- imagine Brabantio would react? And so forth. With the half line, «Her father loved me,» Ko continues:

Othello provided a fleeting glimpse of what lay inside, beneath the combination of dignified, soldierly calm and irrepressible passion for Desdemona that defined him: the untold backstory behind the narrated backstory of the wooing. The untold backstory belonged, not to the world of epic adventure and exotic climes, but to the decidedly social world of Venice... (2012: 6) ${ }^{6}$

6. Ko refers to the 2008 Shakespeare and Company (Lennox, MA) production of Othello. Beyond this production, however, he explains the theoretical debates about character as a critical category, using Othello as an example and thus rehearses A. C. Bradley's favorable argument in Shakespearean Tragedy [1904] and L. C. Knight's rebuttal in How many children had Lady Macbeth? An Essay in the Theory and Practice of Shakespeare Criticism [1933] (2012: 1-16). 
I imagine the handkerchief also belongs in the «untold backstory» of Othello and Desdemona's relationship, that is, before the play opens. The handkerchief's «narrated backstory," which amounts to two conflicting origin tales, invites, even provokes, our imagining an «untold backstory» that offers some explanation for Othello's lying about its origin: either one of the two tales is true or neither is true, but the two we hear him tell cannot both be true. Either an Egyptian sibyl gave it to Othello's mother who gave it to him or his father gave it to his mother; in neither tale does Othello mention the strawberry embroidery that defines it in the social world of the play. To explore what the strawberry emblem could mean to him is to explore what it would have meant to an early modern Venetian general, with one caveat. This Venetian general is as much a Moor in Venice as he is a Moor of Venice: he is an insider and an outsider to early modern emblematic culture and thus we must consider the extent to which this bears on his relation to it.

The source material for The Tragedy of Othello, the Moor of Venice is Giovanni Battista Giraldi Cinthio's Gli Hecatommithi (1565). Among the changes and adaptations Shakespeare made is one about the embroidery on the handkerchief. In Cinthio's version, the handkerchief «was most delicately embroidered in the Moorish fashion [alla moresca]" (Neill, 2006: 439). I imagine the "Moorish fashion" means non-representational figures and geometric shapes, not like the symbolic pictures we see gathered in emblem books and depicted in European decorative arts, such as in women's handkerchiefs. Women's handkerchiefs in the Renaissance, as Bella Mirabella writes, were «engaged in an elaborate social performance with multiple dimensions, playing a role as an object in the material culture of textiles and fashion, a token in a visual economy to be read and interpreted...«(2011, 61). In the economy of commerce, Mirabella continues, the handkerchief could facilitate «the conveyance of money in exchange for an elixir or potion," and, in this economy, women would assist alchemists by "putting the remedy into the handkerchief and passing it along" to buyers (2011, 70-71). In Cinthio's version of the story, the ensign (i.e., Iago) steals the handkerchief without the lady's (i.e., Desdemona's) knowledge, whereas, in Shakespeare's version Desdemona offers to bind Othello's head with it-perhaps in a gesture of healing. He pushes it away with the claim, "Your napkin is too little. / Let it alone" (3.3.285-86) -it drops in this moment and Emilia later picks it up. However this moment between Desdemona and Othello is performed or whatever its stage directions, the language implies that Desdemona moves to comfort her distraught husband with the handkerchief. The language implies, moreover, that Othello is uninterested in the handkerchief, which, had he not genuinely believed it to be some charm against adultery, why would he not now be fixated on it? Especially since the possibility of adultery is precisely his distress? Why? Because I think he does not believe "there's magic in the web of it" (3.4.66).

Shakespeare deliberately removes a hint of the exotic from the handkerchief when he exchanges Cinthio's Moorish design to the emblem demonstrably known to him and popularly available to his English audiences, namely Latet anguis in herba ("a snake lurks in the grass") with the strawberry illustration featured in Paradin's and Whitney's editions. It is the only emblem I have discovered with strawberries on it: I imagine it as Othello's emblem, and I imagine he shared it with Desdemona before the play opens. As an insider to Venetian culture, Othello would have known how emblems signified as Robert Klein explains this in "The Theory of Figurative Expression in Italian Treatises on the Impresa" (1979). Paolo Giovio, in Dialogo dell'imprese militari e amorose (Rome, 1550), says that the imprese expresses «a rule of life or the personal aspirations of its bearer" (Klein, 3). He notes that the French call it a devise and that it was «introduced in Italy by Charles VIII's captains, and was 
imitated by Italian warriors who drew imprese on their weapons» (Klein, 1979: 3). In Il Rota ovvero dell'imprese (Naples, 1562), Scipione Ammirato calls it "a philosophy of the knight» and claims «the first collections of imprese contained only 'amorous and military' or simply 'heroic' devices» (Klein, 1979: 4). The Italian theorists, moreover, turned the emblem inward-for Andrea Chiocco, an academician like Giovio and Ammirato, the impresa was «'an instrument of our intellect, composed of figures and words which represent metaphorically the inner concept of the academician'» (Klein, 1979: 5). An emblem performs an aspect, an aspiration, a moral authority of its bearer: there is an inner to its outer design that encourages its onlookers to discern motive and frame its bearer's behavior. Othello, as a chivalric warrior for Venice, and one in love with a Venetian, would have chosen carefully his emblem and understood its dramatic potentials. Latet anguis in herba is as much an explication of hidden treacheries as it is a warning of them to its bearer.

Shakespeare also would have understood how emblems meant. George Puttenham's Arte of English Poesie (1589) strikingly defines emblems as

short, quick, and sententious propositions, such as be at these days all your devices of arms and other amorous inscriptions which courtiers use to give and also to wear in livery for the use of their ladies, and commonly contain but two or three words of witty sentence or secret conceit till they [be] unfolded or explained by some interpretation. For which cause they be commonly accompanied with a figure or a portrait of ocular representation .... The Greeks call it emblema, the Italians impresa, and we, a device. (My emphasis, 190-91)

Civilized men gave their emblems to their ladies and, as Puttenham notes, emblems were not only verbal but also visual -his phrase "ocular representation» of course resonates strongly with Othello's charge that Iago give him «ocular proof» of Desdemona's adultery (3.3.365). Puttenham's prime example of "ocular representation» is Queen Elizabeth I's emblematic portrait, which appears in his book's frontispiece: the queen stares at us from her near-frontal pose, mouth closed and eyes wide open, framed within an ambiguous motto that, translated from the Italian, says, «To her who resembles herself and no one else» [fig. 4]. Not unlike Alberti's "winged eye» or the Duchess of Urbino's «S," Queen Elizabeth's emblem evokes the singularity of her stature even as it provokes speculation about it: why is the motto addressed to the queen rather than to its audience? Why is it that she «resembles» rather than «identifies» with herself? Notably, Puttenham underscores that the emblematic image -a figure or a portrait- is an "ocular representation.» We may ask: why "representation" rather than "presentation"? "How does the visual image articulate, if it does, with the verbal image?» These questions point up the distance emblems open between inner and outer characterization, between what they reveal and what they conceal, and between their visual ("ocular») and verbal ("witty sentence or secret conceit») components. There has to be an inner and an outer for wit and secrecy, for presentation and re-presentation, and for the political audience Queen Elizabeth's emblem addresses.

In Emblems for a Queen: The Needlework of Mary Queen of Scots (2008), Michael Bath writes extensively on the handiwork of Queen Elizabeth's royal cousin and rival. The Queen of Scots left an extensive inventory of embroidered emblems that Bath catalogues and, in the process, suggests how she used them to express her political, religious, and personal values-overtly and otherwise. By tracing her embroideries to their sources in well known Continental emblem books, Bath demonstrates that Mary refashioned them to her purposes by «inventive variation and reduplication»: "That variation of details -an old motto with a new image, or a new motto for an inherited device- is absolutely characteristic of the way 
emblems were invented in a bricolage of received ideas at this period" (9). Bath illustrates this point by comparing Paradin's Latet anguis in herba to Mary's use of it in the so-called Marian Hanging. This is a collection of thirty-seven emblematic panels embroidered in silk and mounted on a large backdrop, which was created over the period 1565-1585 by Mary and Elizabeth (Bess) Talbot, Countess of Shrewsbury, while Mary was imprisoned in one of the Shrewsbury estates. In a single octagon panel, the queen stitched Paradin's motto around the image of a snake entwined at the base of a strawberry plant [fig. 5]. The image does not exactly copy Paradin's woodcut, however, and Bath points out that the relationship between the moral and Mary's own life is enigmatic: "We have no way of knowing who or what Mary... thought the snake might be that lay in» the grass and how it applied to her life (37). I would say that by transforming a generalized moral emblem into her device, the queen creates an ambiguity that posterity cannot resolve but that contemporaries might have readily understood. In this regard, Mary Queen of Scots and Queen Elizabeth were not unalike in dramatizing their secrets and making this integral to their public characters -in both cases, the ambiguity and the secrecy lent power and prestige to their self-fashioning.

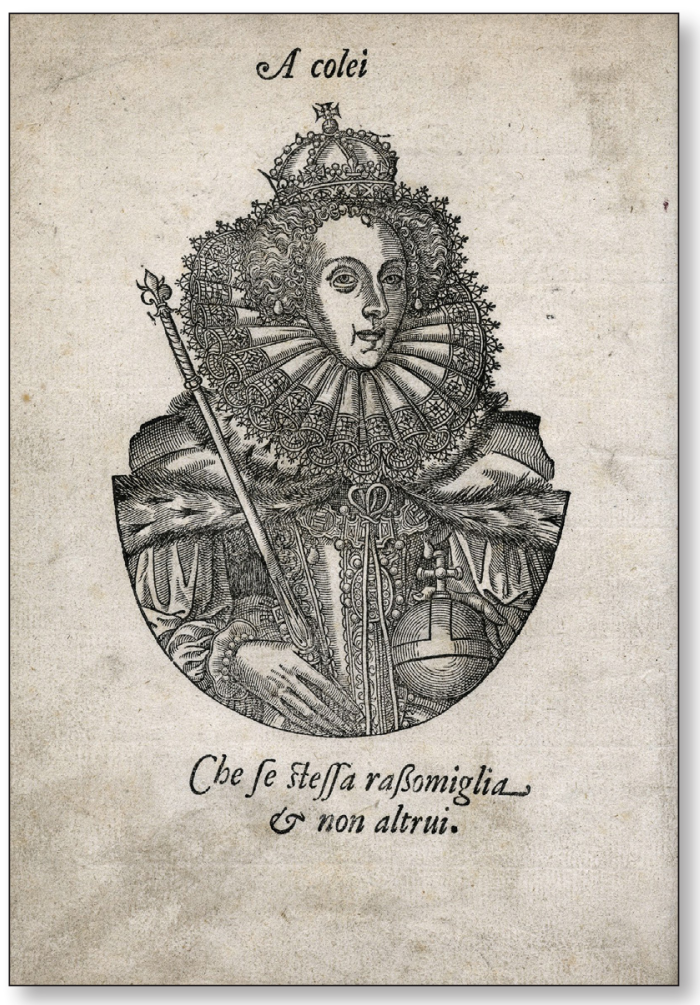

Fig. 4. Frontispiece. George Puttenham, The Arte of English Poesie (1589). Used by permission of the Folger Shakespeare Library under a Creative Commons Attribution-ShareAlike 4.0 International License.

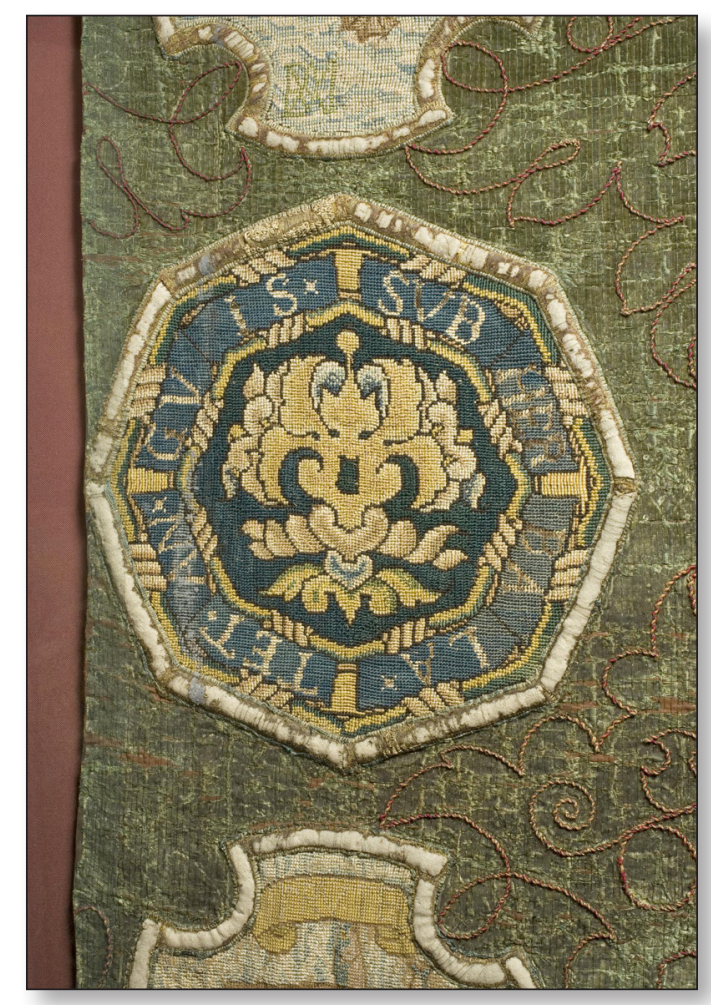

Fig. 5 . The Marian Hanging (detail, panel of Latet anguis in herba). () Victoria and Albert Museum, London. 
Michael Bath makes a couple of points that I would underscore. First, in Paradin the herba are clearly strawberries, or a strawberry-like plant, whereas in Mary Queen of Scots's embroidery the herba is a "plant slip" or a «slip decoration," which comes from the "habit of taking cuttings-a 'slip' was the word for a twig or shoot used in grafting or planting" (Bath, 113). Second, plant and fruit emblems were associated with florilegia ( «bunches of flowers») -collections of proverbial expressions from Latin and Greek writers- through the visual metaphor of the "slip" or "slip decoration" that Mary used. Many emblematists copied their mottos from anthologies of adages, such as Erasmus' Adagia, and encircled the mottos around various plant or fruit slips, thereby consciously relating a verbal poesy ( «flowers of rhetoric») with a visual posy. The relation of the emblematic word to the emblematic picture in these were often a conceit that lovers shared, and this so-called «language of flowers» is evident in John Donne's Elegy 6.

The speaker in Elegy 6 (Natures Lay Ideott) is an Ovidian praeceptor amoris, whose married mistress, having been his excellent student, apparently has betrayed him with those very sophistries and subtleties of love he taught her. The Elegy is an angry screed addressed to her, enumerating the «love-tricks» he now regrets imparting, and among them is the «language of flowers»:

I had not tought thee then, the Alphabett

Of flowers; how they devisefully beeing sett

And bound vp, might with speechlesse secrecy

Deliuer arrands mutely and mutually.

(Donne, 2000: 127, my emphasis, lines, 9-12). ${ }^{7}$

The lover has given her a devise sewn or "sett" with slip decoration without the motto -we can infer that this is an amorous emblem that they previously enjoyed and «spoke» to them. The devise sans motto creates the "speechless secrecy" of an illicit love affair even as it enables a private communication between them, "mutely and mutually.» Donne's poem envisions the amorous devise gone wrong and the lover's attempt to express his emotional outrage over its shared secret rejected or violated. Not unlike this devise, I imagine the strawberries in the handkerchief Othello gave Desdemona were stitched with slip decoration.

With some stretch of the imagination, we could hear a jealous Othello at the very end of the play speaking the lover-poet's words -with more tonal and volume control- to the silent, stunned Desdemona whom he believes an adulterer. Alternatively, we could imagine these words an interior monologue of Othello's when Iago presents him with the "ocular proof» of Desdemona's adultery. The proof, which we know is no proof, is Othello's seeing the "dumb show," with Bianca's refusing to copy the strawberry motif for Cassio. We overhear Bianca's angry words to Cassio:

What did you

Mean by that handkerchief you gave me even now? I was a fine fool to take it. I must take out the work? A likely piece of work, that you should find it in your chamber and know not who left it there. This is some minx's token -and I must take out the work? ... Wheresoever you had it, I'll take out no work on't. (4.1.140-46)

7. For extensive critical commentary on Elegy 6, see The Variorum Edition of the Poetry of John Donne (2000: 625-47). 
In this prose passage, filled with dramatic irony and intrigue, Bianca insistently refers to copying the "work» as taking it out, of which she will have none. What we hear, however, and what Othello sees are two different things. He sees his devise in the hands of a prostitute and now believes that Cassio has had both the handkerchief and Desdemona. His love and his emblem have been whored, and the two may now be inseparable for him.

To stretch one's imagination just a stitch further, this imagined violation of his amorous chivalry could be the "cause» Othello utters just before he murders his wife: "It is the cause, it is the cause, my soul. / Let me not name it to you, you chaste stars: / It is the cause" (5.2.1-3). There is a limit to my comparison, however, for Donne's libertine speaker has taken a mistress and Othello believes his wife becomes one. The speaker is a consummate lover, an insider to the Ovidian love tradition in which he encultures his mistress, whereas Othello is a consummate outsider to the European culture he adopts. The "narrated backstory" he tells the Senate of his wooing Desdemona exemplifies his outsider status as does the romance narratives he tells her. That he proclaims to the Senate, "Rude am I in my speech," is a disarming rhetorical move, however, that bespeaks his sophistication and decorum (1.3.81) -he knows how best to persuade the cultural elite by performing his alien status, not unlike the tutoring of Desdemona that wins her devotion, despite and perhaps because he is not a "wealthy curlèd darling" of Venice (1.2.68). His love, not unlike Donne's speaker's, is cosmopolitan, but his self-possession is less secure than Desdemona believes. Desdemona may be mistaken, but she is not like the innocent mistress of Elegy 6 as the speaker defines her:

\author{
Since houshold charmes thy husbands name to teach \\ Were all the love-tricks that thy witt could reach. \\ And since an howres discourse could scares haue made \\ One answer in thee, and that ill arrayed, \\ In broken Proverbs, and torne sentences. (Donne, 2000: 127, lines 15-19)
}

Before his several language-of-love lessons, the mistress played silly, girlish games, turning to "charmes» or word-games to discover her future husband's name. Before she became articulate in love, she could only recite «broken Proverbs, and torne sentences» about it. Desdemona is as skeptical of charms as she is of the sorry truisms her father ascribes to her fair sex.

The passion Desdemona expresses towards Othello, before the Senate and when they reunite on Cyprus, shows a mature self-awareness, with a touch of bodily transcendence such that I take her phrase, "I saw Othello's visage in his mind" to mean (1.3.249) -this "visage» is the inner principle that chivalric devises express. When Donne's lover-poet elevates his discourse, on the other hand, he does so to mock the sentiments of chivalric romance. He imagines that he cultivates his mistress as God did Eden: «I planted knowledg and lifes tree in thee» (26). This association is outlandish, but not unlike many of Donne's lovers who see themselves divine and make blasphemous comparisons. This lover makes another double entendre that is extraordinary, however, and gives me pause because it associates making an emblem with making love. He says to his mistress: I «inlayed thee . . . I As myne» (lines, 22-23). "Inlaid," as Donne and Shakespeare -and their audiences- very well knew was a defining quality of the early modern emblem, namely that its figures are «inlaid» or stitched as the strawberry motif in the handkerchief.

Early modern textbook definitions of the emblem compare it to a mosaic, an appliqué, or an inlaid ornament. For emblematist Guillaume Budé, «emblem means mosaic work which is made up into a fitting whole out of small inlaid stones» (Miedema, 1968: 217).

IMAGO, NÚM. 8, 2016, 6I-75 
Thomas Thomas's Dictionarium Linguarium Linguae Latinae et Anglicanae (1587) defines emblem as a "Picture worke of wood, stone, or mettall, finelie set or painted in divers coloures, as in chesse bourdes and tables: small images, flowers, or like ornamentes set on plate, or other thing by a vice, to take off, and put on when we will.» Emblems were textured and ornamental, and they could be portable - «to take off, and put on when we will.» We could easily hear Donne's speaker reciting this phrase to his betrayer, only for a lingering, ironic after-image to remind him that his mistress has moved on and discarded him for another «ornament.» For Donne's speaker, whoring an emblem may not be so distant from a whoring mistress, or a wife.

We know that many characters in Othello want to copy the strawberry emblem -to take it out as Bianca calls it three times when she refuses Cassio's request to do so. Emilia wants to copy it, and who knows why Iago desires it. The emblem does become common and, as critics frequently note, the handkerchief passes through many hands in the play. It does become a kind of common property, and the early modern meaning of common as whorish does accrue to the handkerchief. It is likewise common for critics writing about the handkerchief to cite Thomas Rymer's infamous review of the play, where he mocked the handkerchief - «so remote a trifle»- as the determining plot device. In A Short View of Tragedy (1693), Rymer wrote: «So much ado, so much stress, so much passion and repetition about a handkerchief! Why was this not call'd the Tragedy of the Handkerchief? What can be more absurd ... ?» (Pechter, 2004: 208). Most critics seem to take Rymer's bait and try to explain that the tragedy is not really about the handkerchief per se but about early modern European notions of probability, wonder, or marriage rituals. ${ }^{8}$ I think that the play could very well be called the Tragedy of the Handkerchief if we imagine a scenario when Othello first gives it to Desdemona with his emblem on it.

I imagine Othello has taken Latet anguis in herba to heart. As an outsider to Venice, he must be vigilant against misreading cues, faces, and culture. The English translation of Paradin's verse commentary speaks directly to this fear:

In reading of authors, and books, which carries a faire shew to the eye, and yielding small delight to the eare, we must be carefull that we runne not into absurd, and wrong judgements, and opinions, $\varepsilon$ by that meanes make shipwracke of our soules.

With the coming of the printed book to Renaissance Europe, misreading authors and their books, now divorced from authorial presence, was a fear of writers and readers alike. In this way, Othello's fear is enculturated, even if he were to adopt it as a modesty topos: he does seem expert at reading those dramatic cues the Venetian Senate posed. The commentary's final line is uncanny, however, when it predicts that misreading signs can «make shipwracke of our soules." In this, we can hear an echo in Othello's lines, when he and Desdemona reunite on Cyprus, after the Mediterranean tempest nearly wrecks their ships. He aligns hers with his soul -«O my soul's joy!» And:

\footnotetext{
If it were now to die,

‘Twere now to be most happy -for I fear

My soul hath her content so absolute

That not another comfort like to this

Succeeds in unknown fate. (2.1.181-85).
}

8. See J. Altman (2010) on probability, P. Yachnin (2002) on wonder, and L. Boose (1994) on marriage rituals. R. McCoy (2010) seems to be the exception. 
In this, Othello looks ahead to a fated future when he and his soul may not be so absolutely united and safe. He dodged this shipwreck, in other words, but is mindful of others: Latet anguis in herba.

Nowhere in Othello is there mention of a snake embroidered in the handkerchief, only the strawberries that I have imagined rendered with the "slip decoration.» I imagine "slip decoration" because this was associated with "flowers of love" in those devises that alluded to their mottos without actually copying them or the complete emblematic picture (as emblem books rendered them). The embroidered posies were allusive and invite the meta-dramatic analysis Michael Bath offered of the Marian Hanging and I of Elegy 6. The "untold backstory» of the handkerchief that I imagine involves Othello's turning the emblem's warning of treachery into a pledge of loyal, mutual love and in so doing turns his greatest fear into a strength. The strawberries are flowers of his love, which he has «taken out," both excerpted from the entire emblem and copied onto the handkerchief he gives Desdemona. And the snake represents Othello's fear -it is the fear of a viper's ambush. As Whitney's verse commentary states, the "vipers vile» is "flattringe speeche," "hatefull hartes," and "fawning mates," which will inevitably try the "truthe» of "the faithfull wight [person]" "Truthe» here means truth as in the medieval troth of allegiance, constancy, and steadfastness- it is the "pledge" that Othello first offers Desdemona with his devise. It is also a pledge of vigilance he first took as his heroic emblem, then shared with his love who as a Venetian civilian perhaps never understands the depth of his fear, the fear that I think sits at his cultivated core: the ambush.

Whitney's version of the Latet anguis in herba includes marginalia indicating the classical foundations of its proverbial wisdom, which are then placed in a mise-en-page footnote. Both references come from Ovid, the first from the Ars Amatoria, which warns of the treachery Donne dramatizes in Elegy 6, and the second from Ovid's Fasti, which warns of military treachery. One can easily imagine Desdemona's reading the marginal abbreviations - «Ouid Art. 1.» and "Idem 2. Fast.»- glancing at them, really, but barely seeing them or seeing them as marginal, as footnotes, rather than as foundational. One can equally envision Othello's carefully reading them and being struck to the core by the reference to Ovid's Fasti:

\section{Sic iterum, sic sape cadunt, vbi vinvere apertè}

Non datur: insidias, armaq[ue] tecta parant.

In this passage from the section on the "Ides of February," Ovid tells the story of the noble Roman Fabii family who leave the city to fight Etruscan enemies from Veii: "So yet again, so oft they fall. When open victory was denied them, they set an ambush of armed men in wait» (Ovid, 1959: 73). That is, when "open victory was denied» the Etruscans, "they set an ambush of armed men" and destroyed the entire Fabii family. It was an utter disaster, a rout, and, in his telling of it, Ovid imagines himself present:

Whither away, ye scions of an illustrious house? 'Tis ill to trust the foe. O noble hearts and simple, beware of treacherous blades! By fraud is valour vanquished: from every hand the foe leaps forth into the open plain, and every side they hold. (Ovid, 1959: 73) ${ }^{9}$

9. "quo ruitis, generosa domus? Male creditis hosti: / simplex nobilitas, perfida tela cave! / fraude perit virtus: in apertos undique campos / prosiliunt hostes et latus omne tenant» (Ovid, 1959: 72). 
«Noble hearts and simple» fell before the fraudulent Etruscans. One can easily imagine Othello's horror at such a military defeat, especially since Ovid early on makes the point that the Fabii left Rome through an unlucky gate. Ovid -writing the Fasti in exile among the barbarians- seems to warn the Fabii about leaving Rome: «The nearest way is by the righthand arch of Carmentis' gate: go not that way, whoe'er thou art: 'tis ominous» (Ovid, 1959: 73). ${ }^{10}$ Ovid's ominous warning is thus encapsulated in Whitney's two-line quotation and re-contextualizes Latet anguis in herba as an ignoble ambush. Ovid here names the snake a barbarian.

The barbarian lurking within suggestively brings to mind Othello's final soliloquy even as it suggestively points to Iago as a Venetian barbarian. It is too simple to say Iago is the anguis [snake] Othello fears, but he brings anguish to him, and, if there is any prophetic token of Othello's fall, it could be his taking the emblem Latet anguis in herba and not heeding its moral, as Whitney's final verse says: «No foe so fell [bitter], nor yet soe harde to scape, / As is the foe, that fawns with freindlie shape.» In this sense and in my imagined "untold backstory," Latet anguis in herba is Othello's emblem, which he in good faith gives to Desdemona fabricated in the handkerchief and which becomes emblematic of their tragic marriage. In my imagined "untold backstory," Othello's giving Desdemona his emblem is his entrusting her with his worst fear -an ambush. Their love transforms this fear, however, into an unguarded strength that tragically leaves him vulnerable to an ambush of his soul.

\section{BIBLIOGRAPHY}

Altman, J. [2010]. The Improbability of Othello, Chicago, University of Chicago Press.

Bатн, M. [2008]. Emblems for a Queen. The Needlework of Mary Queen of Scots, London, Archetype Publications.

Bellamy, E. [1996], "Othello's Lost Handkerchief: Where Psychoanalysis Finds Itself,» in W. Apollon and R. Feldstein (eds.), Lacan, Politics, Aesthetics, Albany, NY, State University of New York Press, 151-79.

Boose, L. [1994], «Othello's Handkerchief: 'The Recognizance and Pledge of Love,'» in A. Barthelemy (ed.), Critical Essays on Shakespeare's Othello, New York, G. K. Hall \& Co., 55-67.

Castiglione, B. [1959]. The Book of the Courtier, C. Singleton (trans.), New York, Anchor Books.

DALY, P. [1979]. Literature in the Light of the Emblem, Toronto, University of Toronto Press.

Daly, P. (ed). [1988]. The English Emblem and the Continental Tradition, New York, AMS Press.

Daly, P. [2014]. The Emblem in Early Modern Europe, Surrey, Ashgate Publishing Limited.

Dixon, J. [1989]. "Pictura, Scriptura, and Theatrum: Shakespeare and the Emblem," Poetics Today, 10, 155-71.

Donne, J. [2000], Elegy 6 (Natures lay Ideott), in G. Stringer (ed.), The Variorum Edition of the Poetry of John Donne, volume 2, Bloomington, Indiana University Press, 127.

FreEMAN, R. [1966]. English Emblem Books, New York, Octagon Books.

Green, H. [1870]. Shakespeare and the Emblem Writers, London, Trübner \& Co.

10. "Carmentis portae dextro est via proxima Iano: / ire per hanc noli, quisquis es; omen habet" (Ovid, 1959: 72) 
Green, A. [1977]. The Tragic Effect, A. Sheridan (trans.), Cambridge, Cambridge University Press.

GreEnblatT, S. [1980]. Renaissance Self-Fashioning: From More to Shakespeare, Chicago, University of Chicago Press.

Hodgson, J. [1977]. «Desdemona's Handkerchief as an Emblem of Her Reputation,» Texas Studies in Literature and Language, 19, 313-22.

KLeIN, R. [1979], "The Theory of Figurative Expression in Italian Treatises on the Impresa," M. Jay and L. Wieseltier (trans.), in Form and Meaning, New York, Viking Press, 3-24.

Ko, Y. [2012], "Introduction,» in Y. Ko and M. Shurgot (eds.), Shakespeare's Sense of Character, Surrey, England, Ashgate Publishing, 1-16.

McCoy, R. [2010], "'The Tragedy of the Handkerchief': Objects Sacred and Profane in Shakespeare's Othello," E. Robertson and J. Jahner (eds.), in Medieval and Early Modern Devotional Objects in Global Perspective: Translations of the Sacred, New York, Palgrave MacMillan, 155-65.

Miedema, H. [1968]. "The Term Emblema in Alciati," Journal of the Warburg and Courtauld Institutes, 234-50.

Mirabella, B. [2011], «Embellishing Herself with a Cloth: The Contradictory Life of the Handkerchief," in B. Mirabella (ed.), Ornamentalism: The Art of Renaissance Accessories, Ann Arbor, University of Michigan Press, 59-82.

NeILl, M. (ED). [2006]. Othello, The Moor of Venice, Oxford, Oxford University Press.

NeILL, M. [2013]. «Othello's Black Handkerchief: Response to Ian Smith," Shakespeare Quarterly, 64, 26-31.

OviD. [1959]. Fasti, J. Frazer (trans.), Cambridge, Harvard University Press.

Pechter, E. (ed.). [2004]. Othello, New York, W. W. Norton \& Co.

Puttenham, G. [2007]. The Art of English Poesy by George Puttenham, F. Whigham and W. Rebhorn, (eds.), Ithaca, Cornell University Press.

Ross, L. [1960]. "The Meaning of Strawberries in Shakespeare," Studies in the Renaissance, 7, 225-40.

Rymer, T. [2004], "A Bloody Farce,» in E. Pechter (ed.). Othello, New York, W. W. Norton $\delta$ Co., 201-10.

SchneIDer, L. [1990]. «Leon Battista Alberti: Some Biographical Implications of the Winged Eye," The Art Bulletin, 72, 261-70.

Shakespeare, W. [2016]. The Norton Shakespeare, S. Greenblatt (ed.), New York, W. W. Norton \& Co.

Sмrтн, I. [2013]. "Othello's Black Handkerchief," Shakespeare Quarterly, 64, 1-25.

Yachnin, P. [2002], "Wonder-effects: Othello's handkerchief," in J. Harris and N. Korda (eds.), Staged Properties in Early Modern English Drama, Cambridge, Cambridge University Press, 316-34. 
